\title{
Efficient production of MgAl layered double hydroxide nanoparticle
}

\author{
Soontaree (Grace) INTASA-ARD ${ }^{1}$, Sareeya BUREEKAEW ${ }^{2}$ and Makoto OGAWA ${ }^{2, \dagger}$ \\ ${ }^{1}$ School of Molecular Science and Engineering, Vidyasirimedhi Institute of Science and Technology, \\ 555 Moo 1 Payupnai, Wangchan, Rayong 21210, Thailand \\ ${ }^{2}$ School of Energy Science and Engineering, Vidyasirimedhi Institute of Science and Technology, \\ 555 Moo 1 Payupnai, Wangchan, Rayong 21210, Thailand
}

\begin{abstract}
A large quantity of MgAl-layered double hydroxide (LDH) nanoparticle was successfully obtained from a single batch from high concentration (as high as $1 \mathrm{M}$ ) of metal salts solution. LDH were obtained by the precipitation at room temperature under ambient pressure and subsequent aging. The phase purity, crystallinity, anion composition, and morphology (shape and size of the LDH crystals) were investigated to characterize the products. Chloride type MgAI LDH with well-defined platy shapes of the lateral size of $50 \mathrm{~nm}$ was obtained with the very high efficiency (approximately $10 \mathrm{~g}$ from the $160 \mathrm{~mL}$ of the starting solution).

(O2019 The Ceramic Society of Japan. All rights reserved.
\end{abstract}

Key-words : Layered double hydroxide, Nanoparticles, Precipitation, Aging

[Received July 18, 2018; Accepted October 22, 2018]

\section{Introduction}

Layered double hydroxides, abbreviated as layered double hydroxides (LDHs), are a class of anion exchangeable layered materials having a general formula of $\left[\mathrm{M}^{2+}{ }_{1-x} \mathrm{M}^{3+}{ }_{x}(\mathrm{OH})_{2}\right]^{x+}\left(\mathrm{A}^{n-}\right)_{x / n} \cdot m \mathrm{H}_{2} \mathrm{O}$, where $\mathrm{M}^{2+}$ and $\mathrm{M}^{3+}$ are di- and trivalent cations respectively; $x$ is the stoichiometric coefficient; and $\mathrm{A}^{n-}$ is the interlayer anion. ${ }^{1), 2)}$ The variation of their compositions (various $\mathrm{M}^{2+}, \mathrm{M}^{3+}$, and $\mathrm{A}^{n-}$ as well as $x$ value) and possible tailoring of the morphology (particles with varied size and size distribution and films) made LDHs more attractive for a wide range of application including polymer additive, catalyst and catalyst's precursor, catalyst' support, adsorbent for environmental purification, drug/gene carrier and so on. ${ }^{3)-12)}$ Efforts have been made to synthesize LDH particles with desired composition, shape and size suitable for specific application. The productivity is (larger amount of products from smaller volume of the starting solution) one of the key issues for the practical application as well as for the detailed characterization of materials performances. One of the reliable methods for the high productivity is the solid-state reaction using hydroxide and/or oxide as the starting materials. ${ }^{13)-16)}$ Without using solvent, some LDHs have been prepared by mechanochemical methods, however, it is difficult to control the particle morphology of the resulting LDHs.

Precipitation from aqueous solution of metal salts is the method used most extensively for the preparation of LDHs. LDHs form from the aqueous solutions containing

\footnotetext{
Corresponding author: M. Ogawa; E-mail: Makoto.ogawa@ vistec.ac.th
}

divalent and trivalent metal salts and desired anion during the $\mathrm{pH}$ raise, which is achieved by supplying $\mathrm{OH}^{-}$into the system until the solubility limit of the material is exceeded. The addition of a base into acidic solution ${ }^{17)-20)}$ and the decomposition of urea (or hexamethylenetetramine) by heating (homogeneous precipitation) ${ }^{21), 22)}$ have been done for the preparation of LDHs with varied composition and particle size. In order to control the particle morphology of LDHs precisely and to avoid the formation of unwanted by-product, LDHs have been synthesized from low concentration starting metal salts solutions, resulting in the small amount of the products from a batch. Although there are few reports on the synthesis of LDHs from concentrated solutions of metal salts to obtain large quantity of LDHs from a single batch, ${ }^{13), 23)-29)}$ the morphology of the products (particle shape and size) was not examined carefully. Moreover, the aggregation of the LDH particles with several micron size was reported. ${ }^{13), 27)}$ In the present study, co-precipitation of a LDH from concentrated solutions of metal salts (the highest concentration used for the LDH preparation so far) at room temperature and under ambient pressure was done to successfully obtain nonaggregated nanoparticles of LDH with the high product yield (ca. $10 \mathrm{~g}$ from $160 \mathrm{~mL}$ ) as expected. The nanoparticles thus obtained and the green process for the syntheses are suitable for such application of LDHs as drug/gene carrier, adsorbent and catalyst.

\section{Experimental}

\subsection{Materials}

Magnesium chloride hexahydrate $\left(\mathrm{MgCl}_{2} \cdot 6 \mathrm{H}_{2} \mathrm{O}\right)$ was obtained from Ajax finechem Pty. Ltd. Aluminium chloride hexahydrate $\left(\mathrm{AlCl}_{3} \cdot 6 \mathrm{H}_{2} \mathrm{O}\right)$ was obtained from Aldrich. 
Urea $\left(\mathrm{NH}_{2} \mathrm{CONH}_{2}\right)$ was purchased from Kanto Chemical Co. Ammonia solution (25\%) was obtained from Merck Millipore. These chemicals were used without further purification. Deionized water was obtained from a Milli-Q system (>15 $\mathrm{M} \Omega \mathrm{cm}$, Millipore).

\subsection{Sample preparation}

The MgAl-LDHs were synthesized by using coprecipitation method under ambient pressure and temperature. The starting solution (with the $\mathrm{Mg} / \mathrm{Al}$ molar ratio of 3.0) was prepared by dissolving $\mathrm{MgCl}_{2} \cdot 6 \mathrm{H}_{2} \mathrm{O}(120.0$ mmol, $24.4 \mathrm{~g})$ and $\mathrm{AlCl}_{3} \cdot 6 \mathrm{H}_{2} \mathrm{O}(40.0 \mathrm{mmol}, 9.7 \mathrm{~g})$ into 100 $\mathrm{mL}$ of deionized water. Then, $60 \mathrm{~mL}$ of aqueous ammonia $(25 \%)$ was added dropwise to the solution, while stirring at $200 \mathrm{rpm}$, until the $\mathrm{pH}$ of the solution became 9.5. The total metal $(\mathrm{Mg}: \mathrm{Al})$ concentration of the solution was $1.0 \mathrm{M}$. The suspension after the reaction was aged at different conditions; 1) without aging, 2) room temperature aging, and 3) aging at $80^{\circ} \mathrm{C}$ for 1 day. The suspension was dried by applying two drying methods, one is freeze-drying and one is replacing the solvent with acetone then drying in vacuum oven at $40^{\circ} \mathrm{C}$ for 1 day. The powder samples obtained after the drying were then washed with water $\mathrm{pH}=9$ to remove soluble salt from the product. The products thus obtained by the co-precipitation followed by aging at different conditions are designated as COP-0, COP-25, and COP-80 corresponding to the sample prepared without aging, aging at room temperature, and aging at $80^{\circ} \mathrm{C}$ respectively.

Homogeneous precipitation of MgAl-LDH by the decomposition of urea under hydrothermal reaction was also examined. ${ }^{30)-34)}$ The aqueous urea solution (urea/Al molar ratio of 10) prepared by dissolving urea (451.2 $\mathrm{mmol}$, $24.0 \mathrm{~g}$ ) in $60 \mathrm{~mL}$ of deionized water was added to the solution (with the $\mathrm{Mg} / \mathrm{Al}$ molar ratio of 3.0), which was prepared by dissolving $\mathrm{MgCl}_{2} \cdot 6 \mathrm{H}_{2} \mathrm{O}$ (120.0 mmol, $24.4 \mathrm{~g}$ ) and $\mathrm{AlCl}_{3} \cdot 6 \mathrm{H}_{2} \mathrm{O}(40.0 \mathrm{mmol}, 9.7 \mathrm{~g})$ in $100 \mathrm{~mL}$ of deionized water, giving the total metal ion concentration of $1.0 \mathrm{M}$. The resulting homogeneous solution was transferred into a Teflon-lined autoclave (HIRO Co.) and heated at the heating rate of $8^{\circ} \mathrm{C} / \mathrm{min}$ to $150^{\circ} \mathrm{C}$ and kept at $150^{\circ} \mathrm{C}$ for $24 \mathrm{~h}$ (with the rotation at $20 \mathrm{rpm}$ ). After cooling to room temperature, the solid products were collected by centrifugation (at $20,000 \mathrm{rpm}$ for $10 \mathrm{~min}$ ), washed with deionized water and acetone, then dried in vacuum oven at $40^{\circ} \mathrm{C}$ for 1 day. The product thus obtained by the hydrothermal reaction is designated as HT-150.

\subsection{Characterization}

The powder X-ray diffraction patterns of the products were recorded using Bruker New D8 Advance instrument equipped with a monochromatic $\mathrm{Cu} \mathrm{K} \alpha$ radiation of wavelength $\lambda=0.15406 \mathrm{~nm}$. Infrared spectra of $\mathrm{KBr}$ disks were recorded on a Perkin-Elmer Frontier Fourier transform infrared spectrophotometer at the resolution of 1.0 $\mathrm{cm}^{-1}$. A total 64 scans were recorded for each sample. Scanning electron micrographs (SEM) were obtained on a JEOL JSM-7610F field emission electron microscope without coating.

\section{Results and discussion}

The MgAl-LDH was synthesized by co-precipitation reaction from $1.0 \mathrm{M}$ starting $\mathrm{MgAl}$ solution. The changes in the $\mathrm{pH}$ of the solution and the product amount were summarized in Table 1. The $\mathrm{pH}$ of the starting solutions containing magnesium chloride and aluminium chloride $(\mathrm{pH}=2.1)$ was raised to 9.6 by the dropwise addition of $60 \mathrm{~mL}$ aqueous $\mathrm{NH}_{3}$ solution, resulting in the change from transparent solution to milky suspension indicating the formation of LDH (Fig. 1). The suspension was then aged at different conditions; without aging (COP-0), aging at room temperature (COP-25), and aging at $80^{\circ} \mathrm{C}(\mathrm{COP}-80)$ for $24 \mathrm{~h}$ to see the growth process of $\mathrm{LDH}$ particle after precipitation. No change in the $\mathrm{pH}$ of the suspension after aging at room temperature (COP-25) was observed. In contrast, the $\mathrm{pH}$ of the suspension after aging at $80^{\circ} \mathrm{C}$ for $24 \mathrm{~h}$ (COP-80) decreased slightly from 9.5 to 8.3 . The decrease of the $\mathrm{pH}$ was thought to be due to the removal of $\mathrm{NH}_{3}$ from the suspension and the hydroxide consumption as LDHs. The amounts of the product were 9.7, 10.6, and $10.0 \mathrm{~g}$ from the starting solution $(160 \mathrm{~mL})$, which corresponded to 89,97 and $91 \%$ of the expected yield as the dehydrated LDHs for COP-0, COP-25, and COP-80, respectively. The yield was calculated from the concentration of metal ions in the starting solution to be precipitated as dehydrated $\mathrm{Mg}_{3} \mathrm{Al}(\mathrm{OH})_{8} \cdot \mathrm{Cl}$.

The homogeneous precipitation of $\mathrm{LDH}$ from the hydrothermal decomposition of urea at $150^{\circ} \mathrm{C}$ for $24 \mathrm{~h}$ resulted in the similar change from homogeneous transparent starting solution to milky suspension. During the hydrothermal treatment, urea was hydrolysed to give ammonia and carbon dioxide, which were converted to ammonium and carbonate ions, respectively, to lead the $\mathrm{pH}$ raise from 2.1 to 8.6 which was high enough for the $\mathrm{pH}$ required to precipitate MgAl-LDHs. ${ }^{19)}$ The amount of the product was $14.9 \mathrm{~g}$ from $160 \mathrm{~mL}$ of the starting solution. The product prepared by the homogeneous precipitation under the hydrothermal condition was characterized as a mixture of a $\mathrm{LDH}$ and hydromagnesite $\left[\mathrm{Mg}_{3}\left(\mathrm{CO}_{3}\right)_{4}(\mathrm{OH})_{2} \cdot 4 \mathrm{H}_{2} \mathrm{O}\right]$.

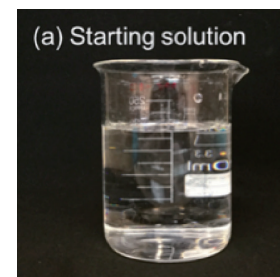

(c) COP-25

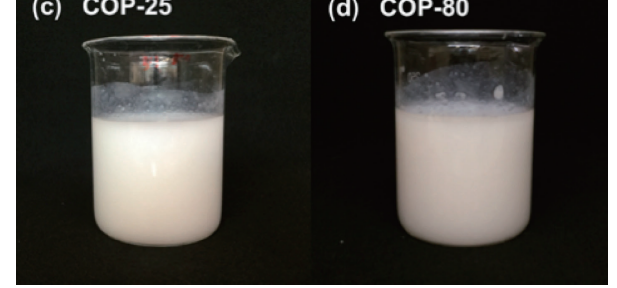

Fig. 1. Photographs of the starting solution (a) and the suspension obtained after the reactions for (b) COP-0, (c) COP-25, and (d) COP-80. 
Table 1. The changes in the $\mathrm{pH}$ of the solution, the product amount, and the yield of MgAl-LDHs prepared by coprecipitation and homogeneous precipitation under hydrothermal condition

\begin{tabular}{|c|c|c|c|c|c|}
\hline \multirow[b]{2}{*}{ Sample } & \multicolumn{3}{|c|}{$\mathrm{pH}$} & \multirow{2}{*}{$\begin{array}{l}\text { Product } \\
\text { amount } \\
\text { (g) }\end{array}$} & \multirow{2}{*}{$\begin{array}{c}\% \\
\text { Yield }^{[\mathrm{a}]}\end{array}$} \\
\hline & $\begin{array}{l}\text { Initial } \\
\text { solution }\end{array}$ & $\begin{array}{l}\text { After the addition } \\
\text { of base }\end{array}$ & $\begin{array}{c}\text { Final } \\
\text { suspension }\end{array}$ & & \\
\hline COP-0 & 2.1 & 9.7 & - & 9.7 & 89 \\
\hline COP-25 & 2.1 & 9.6 & 9.5 & 10.6 & 97 \\
\hline COP-80 & 2.1 & 9.6 & 8.3 & 10.0 & 91 \\
\hline HT-150 & 2.1 & - & 8.6 & 14.9 & n.d. ${ }^{[b]}$ \\
\hline
\end{tabular}

[a] The yield was determined as Yield $(\%)=$ (the amount of product/ expected amount) $\times 100$, by assuming that all the used magnesium and aluminium ions are precipitated as the $\mathrm{LDH}$ of the formula of $\mathrm{Mg}_{3} \mathrm{Al}(\mathrm{OH})_{8} \mathrm{Cl}$. [b] not determined because of the presence of byproduct.

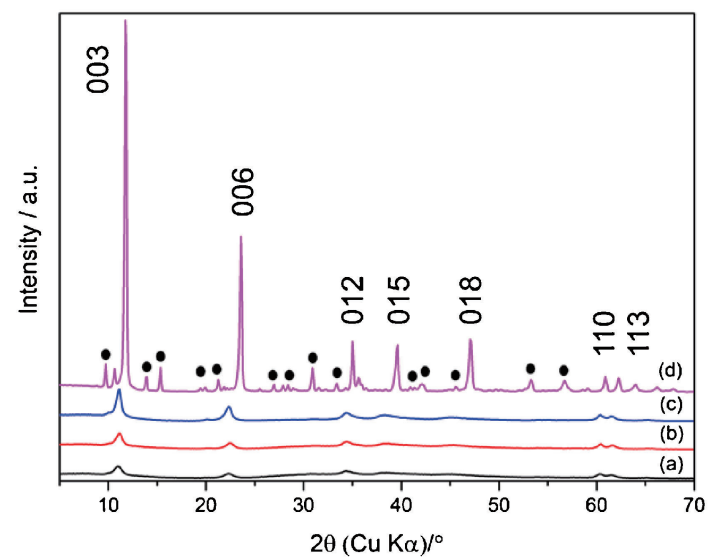

Fig. 2. XRD patterns of MgAl-LDH prepared from coprecipitation method with different aging conditions (a) COP-0, (b) COP-25, (c) COP-80, and (d) HT-150, which was prepared by homogeneous precipitation under hydrothermal condition at $150^{\circ} \mathrm{C}$. Reflections due to hydromagnesite $\left[\mathrm{Mg}_{3}\left(\mathrm{CO}_{3}\right)_{4}(\mathrm{OH})_{2}\right.$. $4 \mathrm{H}_{2} \mathrm{O}$ ] are marked by $(\mathbf{O})$.

The presence of hydromagnesite indicated that the $\mathrm{LDH}$ is not $\left[\mathrm{Mg}_{3} \mathrm{Al}(\mathrm{OH})_{8}\right]\left(\mathrm{CO}_{3}\right)_{1 / 2}$ but a $\mathrm{LDH}$ with $\mathrm{Mg} / \mathrm{Al}$ ratio smaller than 3.0. The possible hydration of the products also affects the amount of the product.

The phase purity, crystallite size, and basal spacing of MgAl-LDHs were shown in Fig. 2 and Table 2. The MgAl-LDH (HT-150) prepared by the thermal decomposition of urea under the hydrothermal condition [Fig. 2(d)] exhibited intense and sharp diffraction peaks, indicating the high crystallinity of material. The $d(003)$ value was $0.76 \mathrm{~nm}$, which is typical d value of the MgAl-LDHs containing carbonate as the interlayer anion. ${ }^{1)}$ Carbon dioxide formed as a product of the urea hydrolysis was converted to $\mathrm{CO}_{3}{ }^{2-}$ during the hydrothermal reaction and the $\mathrm{CO}_{3}{ }^{2-}$ thus formed was preferentially incorporated as the interlayer anion of $\mathrm{LDH}$ due to the high affinity between $\mathrm{CO}_{3}{ }^{2-}$ and LDH sheets. The crystallite size in the c direction (the stacking direction) was estimated from the full width at half-maximum (FWHM) of the 003 diffraction by means of the Scherrer equation $[\mathrm{L}=0.89 \lambda / \beta(\theta) \cos \theta$, where $\mathrm{L}$ is the crystallite size, $\lambda$ is the wavelength of the radiation,

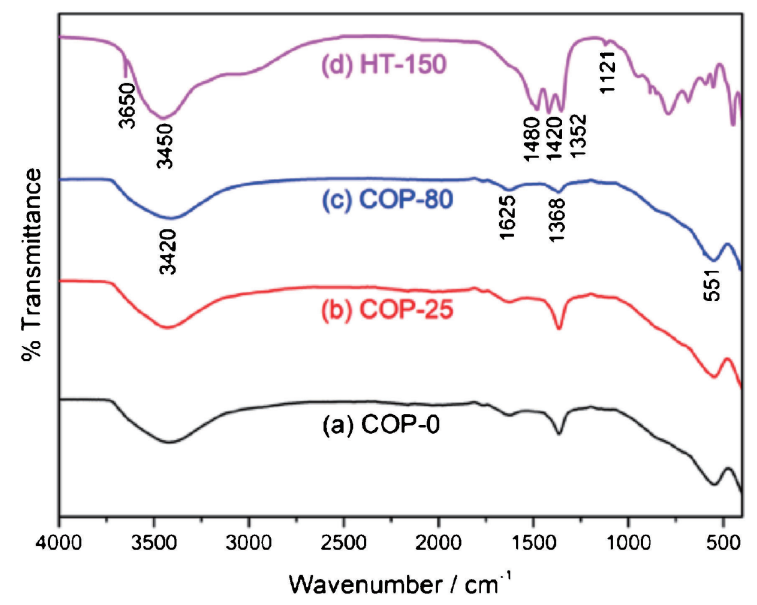

Fig. 3. FT-IR spectra of samples prepared from co-precipitation reaction at room temperature and ambient pressure without aging (a), aging at room temperature (b), aging at $80^{\circ} \mathrm{C}$ (c) compared with the sample prepared by the hydrolysis of urea under a hydrothermal condition at $150^{\circ} \mathrm{C}(\mathrm{d})$.

$\theta$ is the Bragg diffraction angle, and $\beta(\theta)$ is the FWHM] to be $41 \mathrm{~nm}$. In addition, there were weak diffraction peaks at $2 \theta$ of $9,13,15,21,23$ and 31 (corresponding to the $\mathrm{d}$ values of $0.92,0.66,0.59,0.42,0.33$ and $0.29 \mathrm{~nm}$, respectively), ascribable to hydromagnesite (ICDD PDF \#00-008-0179) as by-product from the synthesis. For the LDH preparation under hydrothermal conditions, hydromagnesite was reported to form when $\mathrm{Mg} / \mathrm{Al}$ ratio in the starting solution is higher than 2.0. ${ }^{35), 36)}$ It is difficult to remove hydromagnesite from the products by post synthetic treatments and the presence of the by-product may limit the application.

The samples prepared by co-precipitation showed the X-ray diffraction (XRD) patterns of the LDHs with broad reflections suggesting the smaller particle size and lower crystallinity [Figs. 2(a)-2(c)]. The d(003) value was 0.79 $\mathrm{nm}$, which corresponded to the $\mathrm{Cl}^{-}$as anion present in the interlayer space of $\mathrm{LDH} .{ }^{1), 17,37)} \mathrm{The}^{-}$type $\mathrm{MgAl}-$ LDHs are useful for the anion exchange reaction, and various anions have been reported to be ion exchanged with $\left.\left.\left.\mathrm{Cl}^{-} .1\right), 38\right), 39\right)$ So, the application of the LDH as the starting materials for functional host-guest system is promising. The crystallite size in the $\mathrm{c}$ direction were calculated to be 9, 11 and $16 \mathrm{~nm}$ for the MgAl-LDH without aging (COP0 ), aging at room temperature (COP-25), and aging at $80^{\circ} \mathrm{C}$ (COP-80), respectively, suggesting the preferentially growth of the LDH particles in stacking direction when higher aging temperature was applied in the reaction conducted from high concentration.

Fourier transform infrared spectroscopy (FT-IR) study confirmed the formation of LDHs in all experiments and provided the information of the by-product. As shown in Fig. 3, the broad absorption bands at around 3400-3500 $\mathrm{cm}^{-1}$ seen for all the samples were assigned to $\mathrm{O}-\mathrm{H}$ stretching mode in the hydroxide sheet and the interlayer water molecules. The absorption at around $1600 \mathrm{~cm}^{-1}$ was attributed to the $\mathrm{O}-\mathrm{H}-\mathrm{O}$ bending vibration of the interlayer adsorbed water. The band at ca. $551 \mathrm{~cm}^{-1}$ attributed to M- 
Table 2. Summary of the d values, the crystallite size, and the purity of the products

\begin{tabular}{|c|c|c|c|c|c|}
\hline \multirow{2}{*}{ Sample } & \multicolumn{2}{|c|}{$\mathrm{d}$ value $(\mathrm{nm})$} & \multirow{2}{*}{$\begin{array}{l}\text { Crystallite size in } \\
\text { c direction }(\mathrm{nm})\end{array}$} & \multirow{2}{*}{$\begin{array}{c}\text { Phase } \\
\text { observation }\end{array}$} & \multirow{2}{*}{$\begin{array}{l}\text { Type of } \\
\text { anion }\end{array}$} \\
\hline & 003 & 110 & & & \\
\hline COP-0 & 0.79 & 0.15 & 9 & $\mathrm{LDH}$ & $\mathrm{Cl}^{-}$ \\
\hline COP-25 & 0.79 & 0.15 & 11 & $\mathrm{LDH}$ & $\mathrm{Cl}^{-}$ \\
\hline COP-80 & 0.79 & 0.15 & 16 & LDH & $\mathrm{Cl}^{-}$ \\
\hline HT-150 & 0.76 & 0.15 & 41 & $\mathrm{LDH}, \mathrm{HM}^{[\mathrm{c}]}$ & $\mathrm{CO}_{3}{ }^{2-}$ \\
\hline
\end{tabular}

[a] $\mathrm{c}=3 \mathrm{~d}_{003},[\mathrm{~b}] \mathrm{a}=2 \mathrm{~d}_{110},[\mathrm{c}]=$ Hydromagnesite.
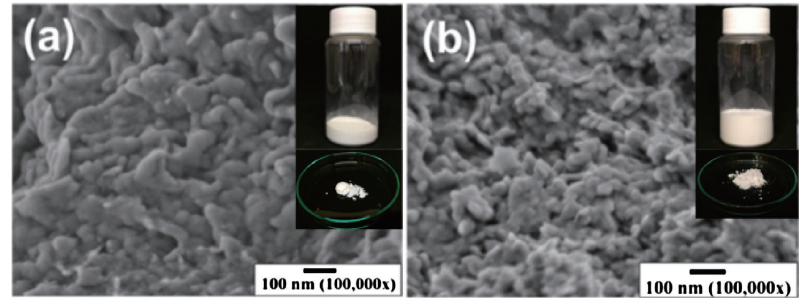

Fig. 4. SEM of MgAl-LDH prepared from co-precipitation followed by aging at room temperature for 1 day (COP-25) dried by (a) vacuum oven and (b) freeze-drying. Inset are the photographs of $5.0 \mathrm{~g}$ products, showing the difference in the bulk density between the two samples (upper), and the as dried products without grinding (bottom).

$\mathrm{O}$ and $\mathrm{M}-\mathrm{O}-\mathrm{H}$ stretching on the hydroxide layer. ${ }^{40)}$ The small absorption peak at $1368 \mathrm{~cm}^{-1}$ corresponding to the $v_{3}$ stretching of $\mathrm{CO}_{3}{ }^{2-}$ contaminant was also presented in the interlayer. ${ }^{40)}$

All the absorption peaks were ascribed to the $\mathrm{LDH}$ indicating the high purity of the LDH obtained from coprecipitation. On the other hand, for the IR spectrum of HT-150, a sharp and intense absorption corresponding to $\mathrm{O}-\mathrm{H}$ stretching of hydromagnesite at the wavelength of $3650 \mathrm{~cm}^{-1}$ and splitted $\left(v_{3}\right)$ asymmetric stretching band (at 1420 and $1480 \mathrm{~cm}^{-1}$ ) and the symmetric stretching band (at $1121 \mathrm{~cm}^{-1}$ ) ascribable to $\mathrm{CO}_{3}{ }^{2-}$ of hydromagnesite were also observed, ${ }^{41)}$ confirming the presence of hydromagnesite as by-product in the $\mathrm{LDH}$ prepared by the homogeneous precipitation.

The presence of carbonate anion in the product is not favorable for the application as ion exchanger and adsorbent. The amount of carbonate varied depending on the conditions. In the case of the product prepared by the hydrolysis of urea under the hydrothermal condition (HT150 ), urea was hydrolysed to give ammonia and carbon dioxide, which were converted to ammonium and carbonate anions, respectively. Since large amount of urea was used to raise the $\mathrm{pH}$ for $\mathrm{LDH}$ precipitation, the presence of high concentration of carbonate anion in the reaction, and the intercalation into the interlayer space of LDH, and the formation of by-product were not easily unavoidable. Whereas, the contaminated carbonate anion in the product prepared by applying co-precipitation method was caused by the dissolution of carbon dioxide from the atmosphere. Therefore, lower amount of carbonate is expected from the product obtained from co-precipitation method.
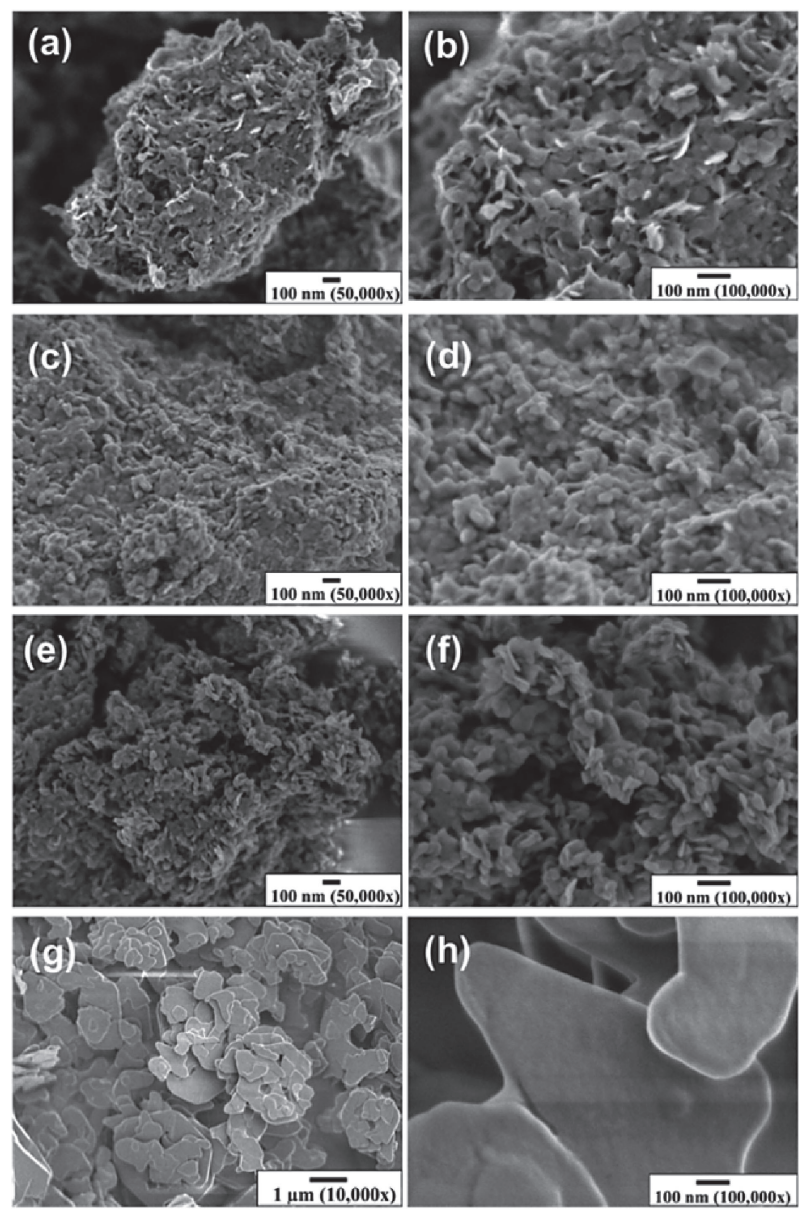

Fig. 5. SEM of the MgAl-LDHs prepared from co-precipitation without aging (COP-0, a-b), aging at room temperature (COP-25, $\mathrm{c}-\mathrm{d})$, aging at $80^{\circ} \mathrm{C}$ (COP-80, e-f), and MgAl-LDH prepared by the hydrolysis of urea under a hydrothermal condition at $150^{\circ} \mathrm{C}$ (HT-150, g-h).

SEM of the products dried at different drying method are shown in Fig. 4. The small LDH particles obtained from the co-precipitation tend to aggregate, which can occur during the particle formation and/or the drying. Freeze-drying was introduced to obtain nanoparticles with less aggregation. ${ }^{42)}$ In the present study, freeze-drying was applied for the precipitates (COP-25) and the product was compared with that dried by the solvent replacement with acetone and subsequent vacuum drying. Freeze-dried MgAl-LDH displayed discrete platy particles with the lateral size ca. $50 \mathrm{~nm}$ [Fig. 4(b)]. In contrast, MgAl-LDH dried by conventional vacuum drying exhibited the aggregated particle with undefined shape and size [Fig. 4(a)]. The difference in the aggregation state can be examined from the bulk density of the dried powder. LDH dried by the freeze-drying presented lower bulk density than that obtained from the vaccum drying (Fig. 4, inset).

The difference in the texture depending on the drying procedure confirmed that the aggregation of particle occurred during drying. The product obtained by the vacuum drying after the washing with acetone was aggregated solid, while the product by freeze-drying was smooth pow- 
Table 3. Characteristics of the MgAl-LDHs obtained from concentrated solution of metal salts and the synthetic conditions

\begin{tabular}{|c|c|c|c|c|c|c|c|c|c|c|c|}
\hline \multirow[b]{2}{*}{$\begin{array}{l}\text { Synthesis } \\
\text { method }\end{array}$} & \multirow[b]{2}{*}{$\begin{array}{c}{\left[\mathrm{Mg}^{2+}+\mathrm{Al}^{3+}\right]} \\
(\mathrm{M})\end{array}$} & \multirow[b]{2}{*}{$\begin{array}{c}\text { Precipitating } \\
\text { agent }\end{array}$} & \multicolumn{2}{|c|}{ Aging } & \multirow[b]{2}{*}{ Atmosphere } & \multirow{2}{*}{$\begin{array}{c}\text { Product } \\
\text { amount } \\
(\mathrm{g} \text { from } \\
100 \mathrm{~mL})^{[\mathrm{b}]}\end{array}$} & \multirow[b]{2}{*}{$\begin{array}{l}\text { Interlayer } \\
\text { anion }\end{array}$} & \multirow[b]{2}{*}{$\begin{array}{c}\text { Observed } \\
\text { Phase }\end{array}$} & \multicolumn{2}{|c|}{ Particle morphology } & \multirow[b]{2}{*}{ Ref } \\
\hline & & & $\begin{array}{l}\text { Temp. } \\
\left({ }^{\circ} \mathrm{C}\right)\end{array}$ & $\begin{array}{l}\text { Time } \\
\text { (h) }\end{array}$ & & & & & Shape & Size & \\
\hline \multirow{10}{*}{ Co-precipitation } & \multirow{3}{*}{0.9} & \multirow{3}{*}{$\begin{array}{l}\mathrm{NaOH} \\
\mathrm{Na}_{2} \mathrm{CO}_{3}\end{array}$} & 65 & 18 & air & $5.9-7.1$ & \multirow{3}{*}{$\mathrm{CO}_{3}^{2-}$} & \multirow{3}{*}{ LDH } & $\begin{array}{l}\text { Poorly } \\
\text { dispersed } \\
\text { unshaped } \\
\text { aggregates }\end{array}$ & Not given & 23 \\
\hline & & & 200 & 18 & $\begin{array}{l}\text { air }+ \text { in } \\
\text { closed } \\
\text { container }\end{array}$ & 5.9 & & & $\begin{array}{l}\text { Well-defined } \\
\text { hexagonal } \\
\text { plate }\end{array}$ & $1 \mu \mathrm{m}$ & 24 \\
\hline & & & 300 & 18 & $\begin{array}{l}\text { air }+ \text { in } \\
\text { closed } \\
\text { container }\end{array}$ & 5.9 & & & $\begin{array}{l}\text { Well-defined } \\
\text { hexagonal } \\
\text { plate }\end{array}$ & $15 \mu \mathrm{m}$ & 24 \\
\hline & \multirow{7}{*}{1.0} & \multirow{3}{*}{$\mathrm{NaOH}$} & No & No & $\mathrm{N}_{2}$ & Not given & $\mathrm{NO}_{3}^{-}$ & LDH & \multirow{4}{*}{$\begin{array}{l}\text { Poorly } \\
\text { dispersed } \\
\text { spherical } \\
\text { aggregates }\end{array}$} & \multirow{4}{*}{$\begin{array}{l}\text { Aggregates } \\
\text { size } \\
10-50 \mu \mathrm{m}\end{array}$} & \multirow{4}{*}{17} \\
\hline & & & No & No & $\mathrm{N}_{2}$ & Not given & $\mathrm{Cl}^{-}$ & LDH & & & \\
\hline & & & No & No & $\mathrm{N}_{2}$ & Not given & $\mathrm{ClO}_{3}{ }^{-}$ & LDH & & & \\
\hline & & $\mathrm{NH}_{4} \mathrm{OH}$ & No & No & $\mathrm{N}_{2}$ & Not given & $\mathrm{Cl}^{-}$ & LDH & & & \\
\hline & & $\mathrm{NH}_{4} \mathrm{OH}$ & No & No & air & 9.7 & $\mathrm{Cl}^{-}$ & LDH & $\begin{array}{l}\text { Uniform platy } \\
\text { particle }\end{array}$ & $50 \mathrm{~nm}$ & $\begin{array}{c}\text { Present } \\
\text { study }\end{array}$ \\
\hline & & $\mathrm{NH}_{4} \mathrm{OH}$ & 25 & 24 & air & 10.6 & $\mathrm{Cl}^{-}$ & LDH & $\begin{array}{l}\text { Uniform platy } \\
\text { particle }\end{array}$ & $50 \mathrm{~nm}$ & $\begin{array}{c}\text { Present } \\
\text { study }\end{array}$ \\
\hline & & $\mathrm{NH}_{4} \mathrm{OH}$ & 80 & 24 & air & 10.0 & $\mathrm{Cl}$ & LDH & $\begin{array}{l}\text { Uniform platy } \\
\text { particle }\end{array}$ & $50 \mathrm{~nm}$ & $\begin{array}{c}\text { Present } \\
\text { study }\end{array}$ \\
\hline $\begin{array}{l}\text { Homogeneous } \\
\text { precipitation } \\
\text { under ambient } \\
\text { pressure } \\
\end{array}$ & 1.0 & Urea & 100 & 36 & air & Not given & $\mathrm{CO}_{3}{ }^{2-}$ & LDH & Not given & Not given & 21 \\
\hline $\begin{array}{l}\text { Homogeneous } \\
\text { precipitation } \\
\text { under } \\
\text { hydrothermal } \\
\text { reaction }\end{array}$ & 1.0 & Urea & 150 & 24 & $\begin{array}{l}\text { In closed } \\
\text { Container }\end{array}$ & 8.6 & $\mathrm{CO}_{3}{ }^{2-}$ & $\begin{array}{l}\mathrm{LDH} \\
\mathrm{HM}^{[a]}\end{array}$ & $\begin{array}{l}\text { Well-crystallized } \\
\text { Unshaped platy } \\
\text { particle }\end{array}$ & $1 \mu \mathrm{m}$ & $\begin{array}{l}\text { Present } \\
\text { study }\end{array}$ \\
\hline
\end{tabular}

[a] HM denotes hydromagnesite by-product. [b] The reported product amount was expressed in a unit of $\mathrm{g}$ (product)/100 $\mathrm{mL}$ (of starting solution).

der. By optimizing the drying condition, it is possible to avoid the particle aggregation.

SEM of the LDH prepared by homogeneous precipitation (HT-150) possessed unshaped platy particles with the lateral size of ca. $1 \mu \mathrm{m}$ [Figs. 5(g) and 5(h)]. Carbonate type MgAl-LDHs have been obtained by the homogeneous precipitation from the lower concentration (level of tens of $\mathrm{mM}$ ) solution of metal salts as the well-defined platy particle with the lateral size of $10 \mu \mathrm{m} .{ }^{30)}$ The smaller particle size reported in the present study was explained as the generation of the large number of nuclei at the initial stage of the reaction thanks to the very high concentration of magnesium and aluminium ions. On the other hand, MgAl-LDH obtained from co-precipitation at room temperature under ambient pressure exhibited much smaller particle size with the diameter ca. $50 \mathrm{~nm}$ as seen in the SEM images [Figs. 5(a)-5(f)]. The particle size (diameter) and shape were not affected by increasing the aging temperature from room temperature to $80^{\circ} \mathrm{C}$. However, the crystal size in the $\mathrm{c}$ direction (stacking direction) was shown to increase when aging temperature was higher, as shown by the calculation from XRD peaks at 003 reflection plane by Scherer equation. The reason of the growth in the $\mathrm{c}$ direction when increasing aging temperature is not clear, while this variation can be a parameter to determine the materials performances. ${ }^{43)}$ In order to extend the size variation and to elucidate the mechanism of the directional growth, efforts are being made in our laboratory using further variation of materials and conditions.

It is difficult to control the particle size and the size distribution of LDHs by co-precipitation methods because the formation of nuclei and the growth take place simultaneously, so that polydispersed particles are obtained. As a successful example of particle size control, LDHs was prepared by rapid mixing of the precursor solutions in a colloid mill to initiates nucleation, followed by a separate aging step to prevent the growth to obtain relatively narrow particle size distribution. ${ }^{44)}$ In the present study, due to the high concentration of metal ions, a large quantity of nuclei formed at the initial stage of the reaction, which grew homogeneously and the growth was terminated due to the limited growth volume for high concentration of the products presence in the reaction.

There are few reports on the preparation of MgAl-LDHs from concentrated solution of metal salts ${ }^{13), 23)-29)}$ as summarized in Table 3. Though the amounts of the products were not given in several papers, the product yields should be similar to the present results as expected from the syn- 
thetic methods. It should be noted that $\mathrm{NO}_{3}{ }^{-}, \mathrm{ClO}_{3}{ }^{-}$, and $\mathrm{Cl}^{-}$type $\mathrm{MgAl}-\mathrm{LDH}$ have been prepared under ambient pressure using decarbonated water and nitrogen bubbling during the synthesis in order to avoid the $\mathrm{CO}_{2}$ contamination. $\mathrm{Cl}^{-}$type $\mathrm{MgAl}-\mathrm{LDH}$ were successfully obtained without decarbonation and nitrogen bubbling, which is an advantageous aspect of the present synthesis. Though the reason is not clear at present, the use of ammonium hydroxide as precipitating agent, which can form complexes with $\mathrm{CO}_{2}$ and keeping in the solution and preventing its intercalation into the interlayer as suggested by the previous report of $\mathrm{MgAl}-\mathrm{NO}_{3} \mathrm{LDH}$ prepared from low concentration, ${ }^{45)}$ and the solubility of carbonate in the solution of the metals salts with different concentrations may be concerned.

LDHs prepared from concentrated (ca. 1 M) solution of metal salts were reported to have low crystallinity, and the particle shapes were scarcely reported as summarized in Table 3. ${ }^{13), 23)-29)}$ Connected (or aggregated) particles of LDHs were also reported. In the present study, a large amount of well-crystallized platy particle of MgAl-LDH with the lateral size of $1 \mu \mathrm{m}$ was obtained by the homogeneous precipitation under the hydrothermal condition at $150^{\circ} \mathrm{C}$ for $24 \mathrm{~h}$ (HT-150). By the co-precipitation under ambient pressure, $\mathrm{Cl}^{-}$type $\mathrm{LDHs}$ with the average size of several tens of $\mathrm{nm}$ were obtained. The concentration of the starting solution has been used as a parameter to control particle size of LDHs. The possible variation of the crystallinity and the particle size depending on the aging condition achieved in the present study motivates the research on the preparation of LDHs and their intercalation compounds from high concentration solutions of metal salts for practical applications.

\section{Conclusion}

The large quantity production of MgAl-LDHs (approximately $10 \mathrm{~g}$ from solution of $160 \mathrm{~mL}$ ) was successfully achieved by using concentrated solution of magnesium chloride and aluminium chloride by the precipitation at room temperature and ambient pressure followed by aging. Freeze drying was effective to obtain the nanometer-sized non-aggregated LDH particles. Chloride type MgAl-LDHs were obtained without a care to eliminate $\mathrm{CO}_{2}$ from the starting solution and during the preparation, which is an additional advantage of the present preparation.

Acknowledgements This work was supported by the Research Chair Grant 2017 (grant number FDA-CO-25605655) from the National Science and Technology Development Agency (NSTDA), Thailand. One of the author (Intasa-ard, S. G.) acknowledges Vidyasirimedhi Institute of Science and Technology for the scholarship to her Ph.D. study.

\section{References}

1) F. Cavani, F. Trifiro and A. Vaccari, Catal. Today, 11, 173-301 (1991).

2) D. Roy, C. Forano and J. P. Besse, "Layered double hydroxides: Present and future", Ed. by V. Rives Nova Publishers, New York (2001) pp. 1-282.

3) F. Li and X. Duan, "Structure and Bonding", Ed. by D. M. P. Mingos, Springer, Berlin Heidelberg (2006) pp. 193-223.

4) T. Selvam, A. Inayat and W. Schwieger, Dalton T., 43, 10365-10387 (2014).

5) K. H. Goh, T. T. Lim and Z. Dong, Water Res., 42, 1343-1368 (2008).

6) P. Saikia, A. Borah and R. L. Goswamee, Colloid Polym. Sci., 295, 725-747 (2017).

7) G. Choi, H. Piao, M. H. Kim and J. H. Choy, Ind. Eng. Chem. Res., 55, 11211-11224 (2016).

8) M. Ogawa and S. Kaneko, Appl. Clay Sci., 75-76, 109113 (2013).

9) R. Ma and T. Sasaki, Accounts Chem. Res., 48, 136-143 (2015).

10) M. Q. Zhao, Q. Zhang, J. Q. Huang and F. Wei, $A d v$. Funct. Mater., 22, 675-694 (2012).

11) M. Shao, F. Ning, M. Wei, D. G. Evans and X. Duan, Adv. Funct. Mater., 24, 580-586 (2014).

12) L. Ma, Q. Wang, S. M. Islam, Y. Liu, S. Ma and M. G. Kanatzidis, J. Am. Chem. Soc., 138, 2858-2866 (2016).

13) W. Tongamp, Q. Zhang and F. Saito, Powder Technol., 185, 43-48 (2008).

14) K. Kuramoto and M. Ogawa, Bull. Chem. Soc. Jpn., 84, 675-677 (2011).

15) K. Kuramoto, S. G. Intasa-ard, S. Bureekaew and M. Ogawa, J. Solid State Chem., 253, 147-153 (2017).

16) S. G. Intasa-ard, K. J. Imwiset, S. Bureekaew and M. Ogawa, Dalton T., 47, 2896-2916 (2018).

17) S. Miyata, Clay. Clay Miner., 23, 369-375 (1975).

18) T. Sato, H. Fujita, T. Endo and M. Shimada, React. Solid., 5, 219-228 (1988).

19) J. W. Boclair and P. S. Braterman, Chem. Mater., 11, 298-302 (1999).

20) H. W. Olfs, L. O. Torres-Dorante, R. Eckelt and H. Kosslick, Appl. Clay Sci., 43, 459-464 (2009).

21) U. Costantino, F. Marmottini, M. Nocchetti and R. Vivani, Eur. J. Inorg. Chem., 1998, 1439-1446 (1998).

22) J. M. Oh, S. H. Hwang and J. H. Choy, Solid State Ionics, 151, 285-291 (2002).

23) W. T. Reichle, J. Catal., 94, 547-557 (1985).

24) W. T. Reichle, Solid State Ionics, 22, 135-141 (1986).

25) W. T. Reichle, S. Y. Kang and D. S. Everhardt, J. Catal., 101, 352-359 (1986).

26) J. W. Boclair and P. S. Braterman, Chem. Mater., 11, 298-302 (1999).

27) S. Miyata, Clay. Clay Miner., 25, 14-18 (1977).

28) S. Miyata, Clay. Clay Miner., 28, 50-56 (1980).

29) S. K. Yun and T. J. Pinnavaia, Chem. Mater., 7, 348-354 (1995).

30) M. Ogawa and H. Kaiho, Langmuir, 18, 4240-4242 (2002).

31) P. Benito, F. M. Labajos and V. Rives, Cryst. Growth Des., 6, 1961-1966 (2006).

32) M. Kayano and M. Ogawa, Clay. Clay Miner., 54, 382389 (2006).

33) M. Kayano and M. Ogawa, Bull. Chem. Soc. Jpn., 79, 1988-1990 (2006).

34) Y. Arai and M. Ogawa, Appl. Clay Sci., 42, 601-604 (2009).

35) S. Miyata, Clay. Clay Miner., 28, 50-56 (1980). 
36) T. Hibino and H. Ohya, Appl. Clay Sci., 45, 123-132 (2009).

37) S. Özgümüş, M. K. Gök, A. Bal and G. Güçlü, Chem. Eng. J., 223, 277-286 (2013).

38) A. Clearfield, M. Kieke, J. Kwan, J. L. Colon and R. C. Wang, J. Inclusion Phenom. Mol. Recognit. Chem., 2, 361-378 (1991).

39) V. Ambrogi, G. Fardella, G. Grandolini and L. Perioli, Int. J. Pharm., 220, 23-32 (2001).

40) J. T. Kloprogge and R. L. Frost, J. Solid State Chem., 146, 506-515 (1999).
41) A. Botha and C. A. Strydom, J. Therm. Anal. Calorim., 71, 987-995 (2003).

42) S. Moriyama, K. Sasaki and T. Hirajima, Appl. Clay Sci., 132-133, 460-467 (2016).

43) M. Ogawa and M. Hiramine, Cryst. Growth Des., 14, 1516-1519 (2014).

44) Y. Zhao, F. Li, R. Zhang, D. G. Evans and X. Duan, Chem. Mater., 14, 4286-4291 (2002).

45) J. Olanrewaju, B. L. Newalkar, C. Mancino and S. Komarneni, Mater. Lett., 45, 307-310 (2000). 